\title{
teksty Teksty Drugie
}

Teoria literatury, krytyka, interpretacja

$4 \mid 2016$

Wojna wstydów

\section{Orgia na dworcu w Jekaterinhofie (O wytwarzaniu Inności w przekładach Idioty Dostojewskiego)}

An Orgy at Yekaterinhof Station: On the Creation of Otherness in Translations os Dostoevsky's The Idiot

\section{Wojciech Tomasik}

\section{OpenEdition}

\section{Journals}

Electronic version

URL: http://journals.openedition.org/td/4933

ISSN: 2545-2061

\section{Publisher}

The Institute of Literary Research of the Polish Academy of Sciences

\section{Printed version}

Date of publication: 1 août 2016

Number of pages: $394-411$

ISSN: 0867-0633

\section{Electronic reference}

Wojciech Tomasik, « Orgia na dworcu w Jekaterinhofie (O wytwarzaniu Inności w przekładach Idioty

Dostojewskiego) », Teksty Drugie [Online], 4 | 2016, Dostępny online od dnia: 15 août 2016, Ostatnio przedlądany w dniu 11 juin 2019. URL : http://journals.openedition.org/td/4933 


\section{Przechadzki}

\section{Orgia na dworcu w Jekaterinhofie (O wytwarzaniu Inności w przekładach Idioty Dostojewskiego)}

Wojciech Tomasik

TEKSTY DRUGIE 2016, NR 4, S. 394-411

DOI: $10.18318 /$ td. 2016.4 .25

$\mathbf{N}$ ie lubiliśmy i nie lubimy Rosji. Dziś mamy do tego szczególne powody. Po katastrofie smoleńskiej, po aneksji Krymu i po zestrzeleniu malezyjskiego Boeinga w dobrym tonie jest mówić o Rosji źle. Na przykład tak: Rosja jest krajem, który nie chce postępować zgodnie ze standardami obowiązującymi w świecie zachodnim. Albo mocniej: Rosja jest krajem nieprzewidywalnym, bez stabilnych struktur demokratycznych, nieszanującym wolności obywatelskich, pozbawionym przejrzystych zasad sukcesji władzy. Albo najmocniej: Rosja jest pijana, nieprzewidywalna, niebezpieczna... „Nieprzewidywalność" to kwalifikacja chyba najczęściej stosowana, gdy chcemy dziś powiedzieć, skąd brały się nasze historyczne lęki, lub gdy mamy uzasadnić, dlaczego dziś także musimy bać się wschodniego sąsiada, w jakim celu potrzebne są nam wojskowe sojusze z Zachodem, czemu chcemy ulokować na polskiej ziemi zachodni sprzęt bojowy (najchętniej ciężki) i po co chcielibyśmy rozmieścić nad Wisłą amerykańskie dywizje (najchętniej pancerne). W zgodnym chórze głosów można usłyszeć oskarżenia najcięższego kalibru: Rosja wspiera światowy terroryzm, gra na globalną destabilizację, zbroi się ponad miarę
Wojciech Tomasik

- prof. dr hab., kierownik Katedry Kultury Współczesnej UKW w Bydgoszczy. Ostatnio publikował: Pociąg do nowoczesności. Szkice kolejowe (2014), Ikona nowoczesności. Kolej w literaturze polskiej (wyd. 2: 2015), Szalony bieg. Kolej i ciemna nowoczesność (2015). Kontakt:woj55@ poczta.onet.pl 
i ekonomiczne możliwości, ma w nosie opinię społeczności międzynarodowej. Nie zamierzam Rosji bronić (sama zrobi to skuteczniej), nie planuję też pytać o racjonalność naszych narodowych lęków. Chcę tutaj zapytać skromnie o to, skąd może brać się „nieprzewidywalność” Rosji, dlaczego tak łatwo nam orzekać, że chodzi o kraj, w którym Inności (Obcości) nie trzeba szukać, ponieważ ta sama się narzuca - wszędzie i w największej dawce. Narzuca się szarym zjadaczom telewizyjnego chleba i serwisów prasowych, ale także tym, których misję postrzegamy jako „przerzucanie mostów”, szukanie dróg wiodących ku zrozumieniu Innego. Taką dostojną misją obdarzamy - zgódźmy się - nie telewizyjnych i prasowych publicystów, ale tłumaczy. Także tych od literatury rosyjskiej.

Ze wszystkich figur, jakie znam z powieści Dostojewskiego, najbardziej podobała mi się zawsze Nastazja Filipowna Baraszkowa. Nie jestem w tym oryginalny, z moim wyborem zapewne zgodziłoby się wielu czytelników Idioty. Ale ja polubiłem tę młodą i piękną kobietę za scenę, którą - podejrzewam pamięta bardzo niewielu, pokochałem mianowicie za mały epizod, któremu żaden z badaczy (myśl moja ogarnia w tym miejscu nie tylko rusycystów) nie poświęcił dotąd uwagi. Oto na początku Części drugiej w charakterystyce głównej bohaterki pada zdanie, z którego dowiadujemy się o „straszliwej orgii na dworcu w Jekaterinhofie, gdzie obecna była również Nastazja Filipowna" (J 190)'. Scena ta (a piszę to z odrobiną wstydu) rozpalała moją wyobraźnię. Orgia jak orgia - myślałem - ale żeby na dworcu? Jak mogła wyglądać? (pytałem siebie prostodusznie), gdzie przebiegała i z czyim udziałem? Orgia w poczekalni? Na peronie? W strugach szampana na stołach w dworcowej restauracji? Kto - prócz pięknej Nastazji i „bandy Rogożyna” - brał w niej udział? Jak zachowywali się numerowi, co brzydkiego robił dyżurny ruchu, na czym przyłapano kasjerów? I jak na to wszystko reagował naczelnik stacji? Brał udział w orgii, przyglądał się beznamiętnie, energicznie protestował? Wiemy, że na dworzec nie zawezwano policji. Nazajutrz po dworcowym zajściu Nastazja Filipowna zniknęła z Jekaterinhofu, podobno pojechała do Moskwy, gdzie przeniosła się także przez nikogo nie niepokojona „banda Rogożyna". Dziwna historia...

Na dworcu można zobaczyć różne sytuacje, na dworcach literackich zdarzają się także takie, których nie spotkamy na co dzień. Ale tam, gdzie rządzi

1 F. Dostojewski Idiota. Powieść w czterech częściach, przeł. J. Jędrzejewicz, przejrzał i poprawił Z. Podgórzec, Puls Publications, London 1992 (cytaty z tego tłumaczenia lokalizuję skrótem J i numerem strony). Pierwsze wydanie ukazało się w 1961 roku. 
poetyka XIX-wiecznego realizmu, repertuar scen dworcowych niewiele odbiega od tego, jaki znamy z naszych codziennych kontaktów z koleją. Czy słyszeli kiedyś Państwo o orgii na dworcu? Albo - pytając trochę mądrzej - czy znają Państwo w literaturze jakiś (jakikolwiek) odpowiednik tego, co przydarzyło się niegdyś w Jekaterinhofie? Ja nie znam. Przeczytałem setki XIX-wiecznych opowiadań i dziesiątki powieści, gdzie bohaterowie coś robią na dworcu kolejowym, i nigdzie nie natrafiłem na scenę, która byłaby porównywalna z przygodą Nastazji Filipownej. Z przekazów współczesnych (XX-wiecznych) przychodzi mi do głowy film Bal na dworcu w Koluszkach, gdzie kolejowa sceneria zmienia swoją funkcję i gdzie między bohaterami różnych płci dochodzi do mniej lub bardziej intymnych zbliżeń. Ale bal na polskim dworcu to jednak coś zupełnie innego, ponieważ - po pierwsze został zorganizowany w sytuacji wyjątkowej, gdy odczuliśmy skutki ataku zimy (podmuch mroźnego Wschodu), a po drugie - nawet w tej ekstremalnej sytuacji zabawa sylwestrowa ani przez moment nie osuwa się na poziom nieobyczajnej orgii. Zapytam teraz o konsekwencje, jakie dla rozumienia Idioty niesie scena z Nastazją. Ponieważ jest to powieść o Inności, o ludziach, których trudno zrozumieć (książę Myszkin, Nastazja Filipowna!), zatem orgia na dworcu może tylko ten ogólny ton wzmocnić. Rosja jest inna, Rosja jest nieprzewidywalna. Dowód? Bardzo proszę: tylko na rosyjskim dworcu można było stać się świadkiem orgii! Bo czy da się jeszcze silniej wygrać inność (nieprzewidywalność) dworcowej przestrzeni, niż czyniąc ją scenerią seksualnego nieopamiętania? Bal w Koluszkach i orgia w Jekaterinhofie to wyraziste wykładniki kulturowego podziału. Tu jest Polska, tam - Wschód. Tu wyrafinowana cywilizacyjnie Europa, tam - zwierzęco nieokrzesana Azja.

Ale sprawa nie przedstawia się wcale tak prosto. Nastazja Filipowna uczestniczyła w orgii na dworcu w Jekaterinhofie niemal przez pół wieku, tyle bowiem funkcjonował u nas przekład Jerzego Jędrzejewicza, który został niedawno zluzowany przez inny -Justyny Gładyś. W tym ostatnim może nas spotkać przykra niespodzianka, nie ma tu bowiem orgii, czytamy tylko o jakiejś „strasznej awanturze na Dworcu Jekaterynhofskim (przy której obecna była i Nastazja Filipowna)" (G 208)². No więc orgia czy awantura (bo wszakże jest między nimi różnica)? Piękna bohaterka brała udział w orgii (co miałoby mocny związek z urodą i młodością) czy tylko była obecna przy awanturze (gdzie wiek i aparycja nie grają przecież żadnej roli)? W jakiej

2 F. Dostojewski Idiota, przeł. J. Gładyś, Zielona Sowa Kraków 2011 (dalej cytaty z tego tłumaczenia lokalizuję skrótem $\mathrm{G}$ i numerem strony). 
awanturze?, pytałem siebie, rozczarowany, że prawdopodobnie jednak nie chodziło o orgię. Dworcowa awantura jest czymś powszednim, nie trzeba być w XIX-wiecznej Rosji, by nabrać pojęcia, jak może takie zajście wyglądać. Dlaczego jednak udział Nastazji w awanturze miałby stać się okazją do towarzyskich plotek? I dlaczego wiedza o dworcowej „awanturze” musiała docierać jakimiś „tajemniczymi kanałami”? Zasadnicza nieprzystawalność obu wersji przekładowych zmusza do postawienia pytania prosto z rejestru szkolnej przepytywanki: gdzie doszło do orgii (lub orgiopodobnej awantury)? Czy zdarzyło się to na dworcu w Jekaterinhofie (jak chciał Jędrzejewicz) czy na Dworcu Jekaterynhofskim (jak proponuje Gładyś)? Jest między tymi lokalizacjami (i tłumaczeniami) wielka różnica. Taka jak między dworcem w Warszawie (np. Dworcem Petersburskim, z którego wyjechał książę Myszkin) a Dworcem Warszawskim w Sankt Petersburgu (dokąd książę na początku powieści przybył). Czy zatem chodzi o budynek dworcowy w Jekaterinhofie czy ulokowany przy jakiejś Kolei Jekaterynhofskiej (jak petersburski Dworzec Carskosielski, z którego wybiegała kolej do Carskiego Sioła i Pawłowska)? Gdzie zatem rozegrała się scena, która tak mocno działała na moją fantazję? Wszystkie pytania, jakie dotąd postawiłem, brzmią - przyznaję - mocno naiwnie. Musieli sobie je jednak postawić (w mniej lub bardziej podobnej formie) polscy tłumacze zmagający się z Idiota, a myślę teraz o Jerzym Jędrzejewiczu i Justynie Gładyś. Musieli je postawić, jeśli chcieli zrozumieć Dostojewskiego i jego Rosję.

Pytanie o Rosję w przekładach Idioty daje się sprowadzić do pytania o natężenie inności. Czy Rosja Dostojewskiego jest krajem, gdzie dworzec może stać się miejscem orgii, a zatem - czy idzie o kraj z polskiej perspektywy w każdym calu inny, gdzie standardowe oczekiwania zachodniego Europejczyka (nie tylko względem dworców) boleśnie zawodzą? Czy może jest to jednak inność pośledniejszego gatunku? Taka, która pozwala o sobie zapomnieć, wszakże awantury na dworcach zdarzały się nie tylko tam i kiedyś, ale przytrafiają się też tu i teraz. Nim zdobędę się na odpowiedź, wrócę do kwestii miejsca, które mogłoby stać się dla polskiego czytelnika ważnym probierzem inności. Jekaterinhof, o którym w Idiocie mowa, jest odwzorowaniem nazywającej się tak niegdyś części Sankt Petersburga (dziś nosi ona oczywiście inną nazwę), niezbyt dużego kompleksu parkowo-pałacowego, położonego na sztucznie utworzonej wyspie. Nigdy nie dotarła tu kolej, nigdy zatem nie postawiono w parku żadnego dworca... Gdzież więc zdarzyło się niegdyś Nastazji Filipownej uczestniczyć w orgii (lub tylko być obecną przy orgiopodobnej awanturze)? Na dworcu w Jekaterinhofie? Na Dworcu 
Jekaterynhofskim? Czy dworcowe zajście (wszystko jedno: orgia czy awantura) jest częścią Rosji Dostojewskiego czy Rosji, którą wytwarzają oba polskie przekłady? Czy XIX-wieczna Rosja jest inna, a jeśli tak, to w jakim stopniu? Czy oba polskie przekłady (w skrawkach tu przywoływanych) inność odwzorowują czy też - produkują?

Współczesna refleksja nad przekładem (identyfikuje się ją niekiedy terminem translational turn) pozwala do kwestii, którą wywołałem, podejść z teoretycznym oprzyrządowaniem. Przekład jest praktyką, która pozostaje w relacjach z innego typu zjawiskami kulturowymi, musi się wobec nich określać, szukać dla siebie uzasadnienia. Nie wszystko się przekłada, a w translacyjnych wyborach warto dostrzec nie tyle preferencje tłumaczy, ile nade wszystko - oczekiwania społeczne. Te oczekiwania nie są zazwyczaj artykułowane wprost, znajdują swoje odzwierciedlenie w polityce przekładowej, którą muszą prowadzić wydawnictwa, by ich działalność nie skończyła się plajtą. Nie chcę bynajmniej powiedzieć, że tłumaczy się wyłącznie to, co się sprzedaje z zyskiem, do polityki przekładowej wydawnictw włącza się bowiem w różnym stopniu interwencjonizm państwowy: państwo przez rozmaite swoje agendy (z Ministerstwem Kultury na czele) może bowiem kształtować rynek czytelniczy i promować dzieła, których wartość nie objawiłaby się nigdy komercyjnym sukcesem. Przekład (myślę wciąż o literaturze) pozwala oswoić to, co drażni lub niepokoi swoją innością. I co pozostaje dokuczliwie nieprzystające do świata, w którym żyjemy i poruszamy się swobodnie. Wiele razy pracę translacyjną nazywano budowaniem kulturowych mostów. Warto wszakże pamiętać, że chodzi zawsze o mosty, gdzie wybitnie uprzywilejowany (lub - wyłączny) jest jeden kierunek ruchu. W przekładzie oryginał zostaje bowiem spacyfikowany, zostaje podporządkowany temu, co językowo (i pojęciowo) nasze, służy nam (bo my za tłumaczenie płacimy!), zostaje wmontowany w nasze lęki i fobie, zestrojony z naszymi projekcjami obcości, zharmonizowany z naszym stereotypem Innego, zmierzony naszymi miarami egzotyczności ${ }^{3}$. Nie są to zatem mosty, a bardziej drabiny, po których usiłujemy wedrzeć się na mury, szturmując kolejną twierdzę Inności. Po szturmie przychodzi czas, by pochwalić się łupami i pokazać już okiełzaną „dzikość". Powiedzieć: zobaczcie, co za niezwykły kraj mamy za sąsiada; tam na dworcach (o zgrozo!) zdarzają się orgie (orgiopodobne awantury). Dziki kraj. My, nawet wtedy, gdy zima kładzie nas na łopatkach, bawimy się na

3 Zob. D. Bachmann-Medick Nowe kierunki w nauce o kulturze, przeł. K. Krzemieniowa, Oficyna Naukowa, Warszawa 2012, s. 289. 
dworcu w Koluszkach najniewinniej w świecie. Jak licealiści na studniówce. W Idiocie prawie wszyscy zasługują na miano dziwnych. Książę Myszkin irytuje infantylizmem, Nastazja Filipowna zdumiewa bezwzględnością i demonicznym temperamentem, prócz nich są jeszcze ludzie żądni władzy, walczący o stanowiska, oszukujący, udający, plotkujący.

Czy polscy tłumacze Idioty nie znali topografii Sankt Petersburga, nie wiedzieli o miejscu, które przeszło do powieści razem ze swoją XIX-wieczną nazwą - Jekaterinhof? Trudno mi sobie wyobrazić kogoś, kto decydowałby się na translacyjny wysiłek i kto programowo zechciałby odciąć się od wiedzy o realiach oryginału. Nie wierzę, by istniał rusycysta z kompetencjami do przekładania Dostojewskiego, który w Sankt Petersburgu nie był i o Jekaterinhofie wcześniej nie słyszał. Zobaczmy zatem, jak z zadaniem Jekaterinhofskim poradzili sobie inni rusycyści-tłumacze. Jak rysuje się postać Nastazji Filipownej w oczach Niemca, Francuza i Anglika? Interesuje mnie wciąż ten ułamek powieściowej biografii bohaterki, który został przez Dostojewskiego zlokalizowany w Jekaterinhofie:

[E]ine Woche nach der schauderhaften Orgie In dem Vauxhall von Jekaterinhof, bei welcher auch Nastasja Filippowna zugegen gewesen war. $^{4}$

[H] uit jours après une orgie formidable au Vaux-Hall d'Ekaterinhof, orgie à laquelle Anastasia Philippovna avait assisté. ${ }^{5}$

[A] week after an awful orgy at the Ekaterinhof Vauxhall, in which Nastasya Filippovna took part. ${ }^{6}$

A dla pełni obrazu muszę jeszcze przedstawić, jak wyglądał fragment szturmowanej we wszystkich przekładach twierdzy Dostojewskiego:

[П]очти ровно через неделю после ужасной оргии в Екатерингофском воксале где присутствовала и Настасья Филиповна. (D 189) ${ }^{7}$

4 F.M. Dostoevskij Der Idiot, Aus dem Russ. von S. Geier, Ammann, Zürich 1996, s. 265.

5 F. Dotoïevski L'Idiot, préface de R. Abello, traduit par A. Mousset, Éditions G.P., Paris 1964, t. 1, s. 494.

6 F. Dostoevsky The Idiot, the new translation by R. Pevear and L. Volokhonsky, Vintage, New York 2003, s. 180.

7 Ф.М. Достоевский Идиот. Роман в четырех частях, Москва 2001, s. 189 (dalej w lokalizacji skrót $D$ i numer strony). 
Bardzo wątpię, aby autorzy zacytowanych fragmentów mieli większą wiedzę o XIX-wiecznym Sankt Petersburgu niż nasi tłumacze. Coś musi jednak uzasadniać to, że ich Rosje (niemiecka, francuska i angielska) są inne niż Rosja polska. Bo w tamtych trzech odbywają się wprawdzie orgie (nie zaś awantury!), ale dochodzi do nich bynajmniej nie na dworcu. Wrócę teraz do myśli o przekładzie jako o oswajaniu obcości. Wszystkie zacytowane teraz fragmenty pokazują, że zasadnicza teza, iż przekładany oryginał znajduje się w krainie Inności, wymaga istotnego uzupełnienia.

Okazuje się bowiem, że wewnątrz szturmowanej twierdzy (tj. w przekładanym oryginale) nie wszyscy chcą bronić niezawisłości, są bowiem wśród obrońców elementy obce, językowi dywersanci, którzy mogą przyjść w sukurs tłumaczowi. Ten bowiem bez trudu odnajdzie w tekście Innego jednostki swojego kodu, takie, których przekładać nie trzeba, ponieważ - nim znalazły się u Innego - były wcześniej w macierzystym języku tłumacza. Niemiecki tłumacz rozpozna, że nazwa Jekaterinhof jest stylistycznym dywersantem, ponieważ stanowi przecież rosyjską kalkę z jego języka. Angielskiego tłumacza ucieszy słowo „воксал”, ponieważ to przecież z jego ojczyzny wziął się skalkowany tutaj rzeczownik pospolity „vauxhall”. W skrawku z powieści Dostojewskiego jest także miejsce na radość Francuza: historycy języka wywodzą nazwę własną „Vauxhall” (a więc tę, która dała początek rzeczownikowi pospolitemu „vauxhall”) od nazwiska pochodzącego z Normandii rycerza-banity (był to ponoć jakiś Falkes, Falcasius lub Falco) ${ }^{\mathbf{8}}$. Niemiec, Anglik i Francuz sięgają do tekstu Dostojewskiego w geście rewindykacji, odnajdując w rosyjskim oryginale coś, co ten - za pośrednictwem medium języka - wcześniej z ich języków zapożyczył. Miejsce XIX-wiecznej Polski (jak zobaczymy) jest w tej układance po stronie, która w XIX wieku dokonywała kulturowych pożyczek. W świecie Dostojewskiego (w jego Rosji) do zachowania Nastazji Filipownej został dopisany współczynnik kulturowej dyfuzji: bohaterka bierze udział w orgii, której tłem jest przestrzeń przeniesiona pod Petersburg z Zachodu (ów Jekaterinhofski vauxhall). W polskiej „orgii na dworcu” nie ujawni się XIX-wieczna kondycja naszego języka, który - podobnie jak język rosyjski - korzystał z dobrodziejstw zapożyczeń. „Dworzec” jest bowiem nasz, w XIX wieku mówiło się jeszcze zamiennie: dwór lub dworzec. Zakopiański „Dworzec Tatrzański” z początku XX wieku pokazuje, że chodziło wtedy o rodzaj okazałej budowli,

8 Zob. L. Tesnière Les Antécédents du nom russe de la gare , Revue des Etudes Slaves” 1951 (XXVII), s. 255 . 
bez względu na jej położenie i przeznaczenie. Sens współczesny „dworca”, ten wykorzystany w przekładach Jędrzejewicza i Gładyś, jest jednak inny. W dzisiejszym „dworcu” ważne jest przeznaczenie budynku, jego silny związek z koleją, położenie w bezpośrednim sąsiedztwie miejsca, gdzie zatrzymują się pociągi osobowe9 . I właśnie to współczesne znaczenie sprawia, że scenę z orgią na dworcu odbieramy jako świadectwo rosyjskiej inności (nieprzewidywalności).

Roztrząsam stale skrawki przekładów, pochodzących z bardzo obszernej powieści. Czytelnik zwykle nie zwraca uwagi na takie drobiazgi. Może zatem nie warto kruszyć kopii, skoro idzie o błąd tłumacza, zwyczajny lapsus? Jekaterinhof zjawia się w Idiocie tylko w tej jednej migawce, potem już go nie ma, bohaterów spotykamy gdzie indziej - w różnych miejscach Sankt Petersburga i w Pawłowsku. Tak, to prawda. Ale gdzie widzimy naszych ulubieńców w Pawłowsku? Co stanowi centrum pawłowskiego kawałka powieściowej przestrzeni? Gdzie zbiegają się wszystkie ścieżki, jakimi poruszają się letnicy? W przekładzie Jerzego Jędrzejewicza tętno życia kulturalnego Pawłowska bije na dworcu. U Justyny Gładyś dochodzi tymczasem do rozbicia pawłowskiego centrum: raz czytamy zatem o dworcu, innym razem o foksalu. Dworzec, foksal czy może jeszcze jakieś inne miejsce? Zobaczmy najpierw, jak to wygląda (jesteśmy - przypomnę - w Pawłowsku):

Na dworcu w Pawłowsku w dni powszednie, jak wiadomo i jak przynajmniej wszyscy twierdzą, zbiera się publiczność bardziej „dystyngowana" niż w niedzielę i święta, kiedy przyjeżdża z miasta dużo różnych ludzi (J 364);

Jak powszechnie wiadomo, a w każdym razie jak wszyscy twierdzą, w dni powszednie na pawłowowskim foksalu gromadzi się publiczność „bardziej wyszukana” niż w niedzielę i święta, gdy zjeżdżają się tłumnie „najróżniejsi ludzie” z miasta (G 397);

Koncert na dworcu już się skończył. W parku nie było zapewne nikogo; oczywiście musiało to być co najmniej pół do dwunastej (J 381-382);

9 Krakowski Dworzec Towarowy (nazwa dobrze utrwalona w topografii miasta), utworzony W 1913 roku, wyłamuje się z tych ograniczeń: nie zatrzymują się na nim pociągi osobowe, nie odbywają się tu odprawy podróżnych (nie ma kas sprzedających bilety). "Dworzec” tutaj to raczej teren, na którym dokonuje się operacji kolejowych, stacja i kompleks budynków (magazynów). Krakowski obiekt nie jest bynajmniej wyjątkiem. Dzisiejszy warszawski Dworzec Główny zachowuje swą nazwę dzięki funkcji, jaką pełnił przez pierwsze powojenne dekady. 
Muzyka na foksalu przestała już grać. Możliwe, że w parku, o tej porze (nie było wcześniej niż wpół do dwunastej) nikogo już nie było. (G 416)

Nie wszędzie jednak „foksal” zastępuje „dworzec”. Popatrzmy tylko:

Tym razem wieczór był cudowny i publiczności dosyć dużo. Wszystkie miejsca wokół orkiestry były zajęte. Nasze towarzystwo rozsiadło się na krzesłach trochę z boku, w pobliżu najbardziej na lewo położonego wyjścia z dworca (J 364-365);

Tym razem nie tylko wieczór był śliczny, ale i publiczność dopisała.Wszystkie miejsca wokół grającej właśnie orkiestry były zajęte. Nasze towarzystwo zajęło miejsca nieco z boku, niedaleko wyjścia ze stacji, położonego najbardziej na lewo (G 397);

Z owego właśnie bocznego wejścia na dworzec, w którego pobliżu ulokował się książę wraz z całym towarzystwem, wyłoniła się nagle spora gromadka ludzi, licząca przynajmniej z dziesięć osób (J 367);

U wyjścia ze stacji, niedaleko którego siedział książę i cała kopania Jepanczynów, pojawił się nagle spory tłumek, złożony z co najmniej dziesięciu osób. (G 400)

„Dworzec” w tłumaczeniu Jędrzejewicza to najczęściej „foksal” w przekładzie Gładyś, ale zdarza się, że „dworzec” to „stacja” (co przed momentem pokazałem). Są też pary: „stacja” (J 445) - „foksal” (G 484), „dworzec” (J 330) - „dworzec” (G 361) i „stacja” (J 624) - „stacja” (G 679). Jeszcze raz przypomnę: rzecz dzieje się w Pawłowsku (przyjdzie nam za chwilę lepiej poznać tę miejscowość), tu rozgrywają się kluczowe dla powieści wydarzenia. „Dworzec w Jekaterinhofie" to króciutka migawka, w Pawłowsku mamy długie zbliżenia, narrator każe nam przyglądać się sprawom z analityczną drobiazgowością. „Koncert na dworcu już się skończył” - dowiaduje się od Jędrzejewicza czytelnik i zapewne reaguje tak, jak na zdanie o orgii na dworcu, w której uczestniczyła Nastazja Filipowna. Jasne, Rosja jest inna: pijana i nieprzewidywalna. To kraj, gdzie na dworcach zdarzają się przedziwne wypadki. Gdy Justyna Gładyś w przekładzie po raz pierwszy używa słowa „foksal”, dodaje do niego odsyłacz, a w przypisie śle czytelnikom pocztówkę z egzotycznego kraju: „Foksal - publiczny ogród botaniczny, miejsce spotkań towarzyskich i rozrywek (koncertów, pokazów sztucznych ogni, występów...); nazwa od londyńskiego ogrodu Vauxhall Gardens" (G 396). Orgia na dworcu, koncerty 
w ogrodzie botanicznym... Dziwni ludzie, dziwaczny kraj! W oryginale we wszystkich przywołanych dotąd fragmentach, tam, gdzie polscy tłumacze kładli „dworzec”, „foksal” lub „stację”, mamy jedno słowo. To samo, które identyfikowało miejsce Jekaterinhofskiej orgii: słowo „воксал”. Co autor, używając go, miał na myśli?

Miał na myśli foksal, rodzaj okazałego budynku, z salą balową i restauracją, nie - ogród (botaniczny). Wspomniany już francuski rycerz-banita Falkes (de Breauté), ożeniwszy się z Margaret de Riparus (Redvers), stał się właścicielem okazałego domu pod Londynem, który źródła historyczne zarejestrowały najpierw jako Faukshale, a później (prawdopodobnie wskutek zniekształcenia) jako Fox hall. Ta ostatnia forma nazwy miejscowej utrwaliła się ostatecznie w brzmieniu Vauxhall i rozszerzyła swój zakres, odnosząc się z czasem do budynku i do najbliższego jego otoczenia. W drugiej połowie XVII wieku założony został tu ogród, udostępniony jako miejsce zabaw i spotkań wykwintnemu londyńskiemu towarzystwu. Szczyt popularności, który przypadł na początki XVIII wieku, ujawnił się także w praktyce przenoszenia formuły organizacyjnej i nazwy parku Vauxhall (znanego teraz jako Vauxhall Pleasure Gardens lub New Spring Gardens) do europejskich metropolii ${ }^{\mathbf{1 0}}$. Długa lista parków naśladujących ideę zrodzoną pod Londynem obejmuje także warszawski vauxhall (foksal), który powstał pod koniec XVIII wieku na terenie ogrodu sąsiadującego z pałacem Czapskich. Ten warszawski obiekt znalazł swoje odbicie w Powrocie posła Juliana Niemcewicza, gdzie Szarmancki opowiada z dumą: „Potem koło dziesiątej, kończąc dzień przyjemny / Foksalowe zabawy okrywał mrok ciemny"11. W latach 30. XIX wieku warszawski ogród Foksal miał już wybitnie rozrywkowe przeznaczenie (można tu było zjeść, napić się i posłuchać muzyki). Nazwę Foksal nosił też budynek na Nowym Świecie, gdzie w 1841 roku otwarto elegancką restaurację $e^{12}$.

Zob. L. Tesnière Les Antécédents..., s. 255-260; R. Stites Passion and Perception. Essays on Russian Culture, New Academia Publishing, Washington D.C. 2010, s. 514.

J.U. Niemcewicz Powrót posła. Komedia w trzech aktach, w: tegoż Powrót posła. Komedia w trzech aktach oraz wybór bajek politycznych, oprac. Z. Skwarczyński, wyd. 9, Ossolineum, Wrocław 1981, s. 51.

„Założywszy nową restaurację przy ulicy Nowy Świat, w domu zwanym Foksal, mam zaszczyt polecić się łaskawym względom Sza[nownej] Publiczności i zarazem donieść, iż dołożę wszelkich starań, aby Prześwietna Publiczność zadowoloną była tak z potraw wszelkiego rodzaju, jako też napojów, których za najpomierniejszą cenę, z rychłą usługą, dostać będzie można" (Nowa restauracja [anons reklamowy], "Kurier Warszawski” 1841 nr 97). Budynek o nazwie Foksal musiał stać dużo wcześniej, skoro w prasie warszawskiej można było znaleźć informację 
W początkach XIX wieku obszar Jekaterinhofu (nazwany tak, ponieważ stanowił dar cara Piotra I dla żony Jekateriny Aleksiejewnej, późniejszej carycy Katarzyny) przeszedł na własność miasta, a tutejszy park (otaczający drewniany pałac) stał się miejscem odpoczynku dla petersburskiej elity. Właśnie w Jekaterinhofie, w południowej części wyspy, został w latach 20. wzniesiony okazały budynek, który miał zapewnić warunki dla organizowania koncertów i zabaw, niezależnie od kaprysów pogody. Budynek szybko zyskał wysoką renomę, stając się ważnym ośrodkiem życia kulturalnego (muzycznego) rosyjskiej stolicy. Był to Vauxhall de Catherinehoff (zob.ilustracja).

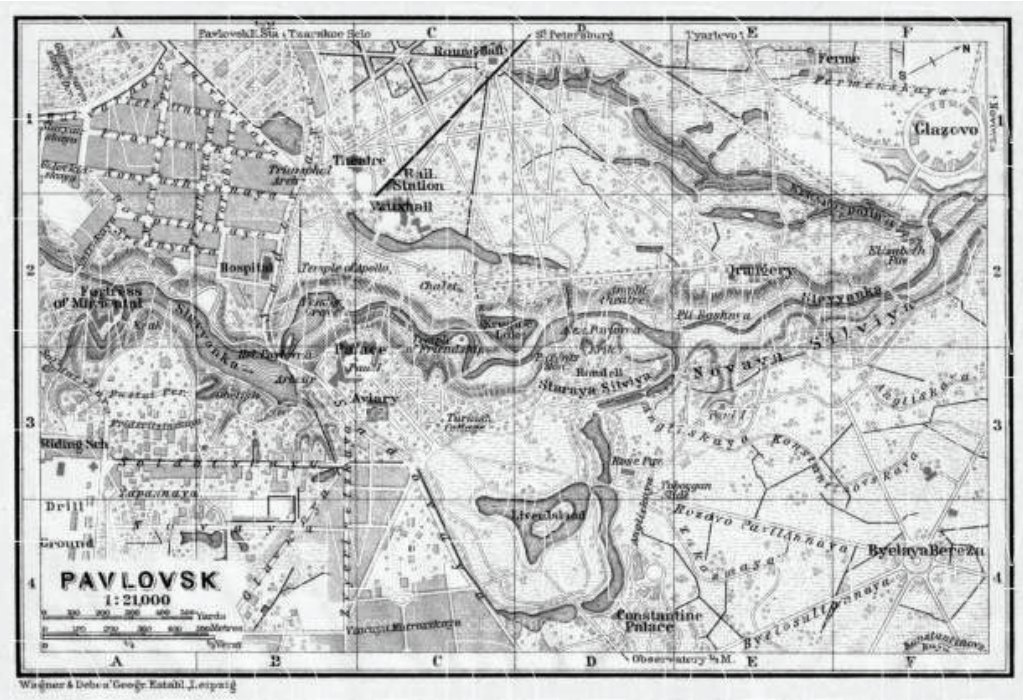

Nazwa musiała szybko ulec apelatywizacji, skoro już w 1838 roku w haśle „воксал”, jakie znalazło się w popularnym leksykonie, dzieje londyńskiego parku rozrywki i charakterystykę stojącej w nim rotundy („gdzie organizuje się koncerty w złą pogodę”) zamyka zdanie: „Dziś na ogół foksalami nazywa się budynki z odpowiednio dużymi salami dla tańców, koncertów itp.,

o braciach Faber, którzy pod koniec XVIII wieku zasłynęli z produkcji fajerwerków „bez żadnego odoru”. Bracia „mieszkali na Nowym Świecie w domu nr 1297, zwanym Vauxhall (Foxal), gdzie zwykle wykonywano ognie sztuczne” ("Kurier Warszawski" 1847 nr 251, s. 1266). Śladem po ogrodzie (i budynku, gdzie mieściła się restauracja) jest dzisiejsza ulica Foksal. 
wzniesione na podmiejskich terenach zabaw publicznych [гульбищ, $а х z]$ "13. Procesowi apelatywizacji sprzyjało to, że w 1838 roku petersburska elita miała do dyspozycji już dwa foksale: do tego w Jekaterinhofie (gdzie w Idiocie bawiła się z fantazją Nastazja Filipowna i „banda Rogożyna”) doszedł bowiem okazały obiekt wzniesiony w parku w Pawłowsku ${ }^{14}$.

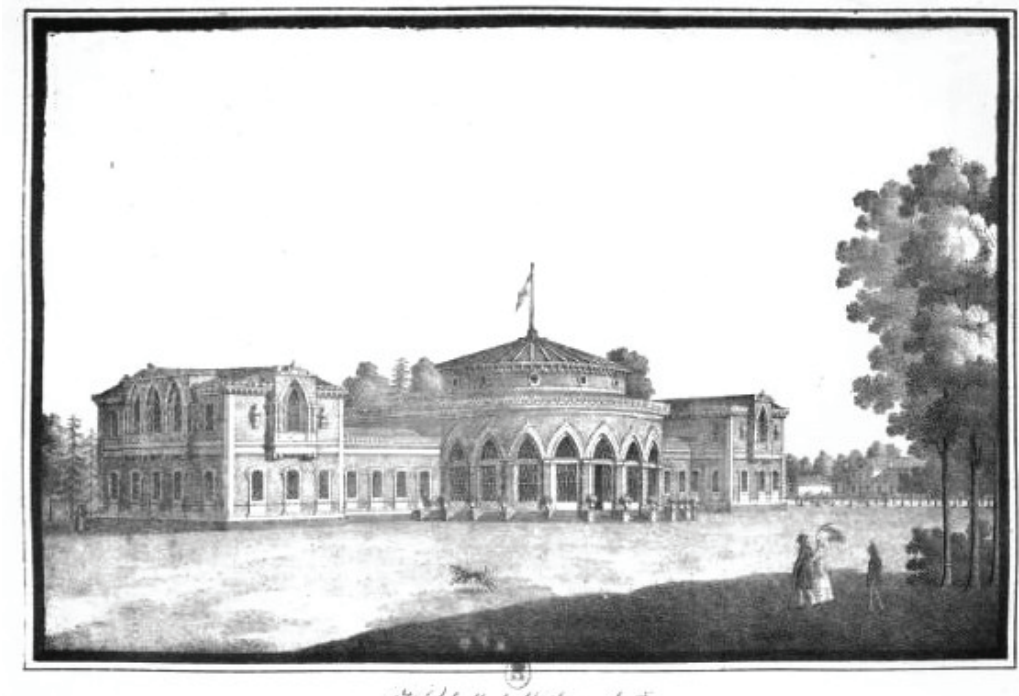

Źródło: Nouvelle collection de quarante-six vues de Saint-Pétersbourg et de ses environs, dessinés d'après nature par divers artistes, St.-Pétersbourg 1827, vue 19.

Historia foksalu w Pawłowsku jest nierozdzielnie spleciona z inicjatywą wybudowania w Rosji pierwszej linii kolejowej. Była to inicjatywa Franza Antona von Gerstnera, austriackiego inżyniera, który wyszedł z założenia, że pierwszą linię kolejową trzeba wyprowadzić z Sankt Petersburga i zapewnić jej wysoką rentowność, aby przekonać władze rosyjskie do nowego środka lokomocji. Gerstner miał zadanie trudniejsze niż inwestorzy z Zachodu. Pierwsza linia nie mogła bowiem w Rosji wkomponować się w rozwiniętą infrastrukturę przemysłową (bo jej nie było), nowy środek transportu musiał zatem szukać uzasadnienia poza sferą gospodarki. Znalazł - w higienie

13 Воксал, [hasło w:] Энииклопедический лексиконъ, t. 11, Санктпетербургъ 1838, s. 294.

14 Zob. R. Stites Passion and Perception..., s. 518-521. 
i rozrywce ${ }^{15}$. Gerstner argumentował: „dzięki niewidzialnej sile pary będzie się podróżować do Carskiego Sioła i Pawłowska z prędkością strzały, będzie się tam oddychać lepszym powietrzem od tego w mieście, które jest położone nisko”. I dodawał: „na końcu drogi żelaznej powstanie nowy park Tivoli, pyszny foksal; zarówno latem, jak i zimą będzie on służył jako miejsce spotkań dla mieszkańców stolicy; gry i tańce, okazja do odświeżenia sił na świeżym powietrzu i w wykwintnej restauracji przyciągną tam każdego"16. Już w 1836 roku, równolegle z zakupem taboru i sprzętu niezbędnego do eksploatacji mającej powstać linii (obszerna lista zakupów obejmowała m.in. zegary i „trąbowe mechanizmy mające obwieszczać mieszkańców Petersburga o przejeździe wozów parowych przez ulice”) Gerstner składał zamówienia na wyposażenie „domu mającego być w Pawłowsku i mogącego służyć za wzór godny naśladowania”. „Tygodnik Petersburski” donosił:

W wystawionym już od lat kilku w Londynie Kolizeum jest ogród zimowy, z bijącą fontanną, który się powszechnie ze swego urządzenia podobał. W budowie przeznaczonej w Pawłowsku do przyjęcia i do zabawy publiczności będzie także założony mały ogród zimowy z fontanną. Do tej roboty przybył już z Anglii p[an] Samuel Gray, który się trudnił urządzeniem fontann w londyńskim Kolizeum i po wielu innych miejscach. Jego pracą stanie fontanna w budowie w Pawłowsku, a przy niej w zimowym ogrodzie będzie sześć mechanicznych krzeseł tak urządzonych, iż siedzący oparciem się o poręcze będzie mógł dowolnie zmieniać kształt fontanny. Prócz tego dwie fontanny letnie staną przed budową. ${ }^{17}$

Jedna rzecz wymaga tu mocnego podkreślenia: „воксал [foksal]” zadomowił się w Rosji jeszcze w kulturze przedkolejowej. Pierwszy z takich obiektów, wzniesiony w parku w Jekaterinhofie, dawał wystarczające pojęcie o tym, czego będzie się można spodziewać po projektowanej budowli w Pawłowsku. W latach 30. XIX wieku, nim jeszcze Rosja poznała zalety drogi żelaznej, znała

15 Zob. R.M. Haywood The Beginnings of Railway Development in Russia in the Reign of Nicolas I, 1835-1842, Duke University Press, Durham 1969, s. 108-158.

16 Ф.А. фон Герстнер, О выгодах построения железной дороги из Санкт-Петербурга в Царское Село и Павловск, Санктпетербургъ 1836, s. 39; cyt. za: L. Tesnière Les Antécédents..., s. 262.

17 Pierwsza droga żelazna w Rosji, „Tygodnik Petersburski” $1836 \mathrm{nr} 65$ i 67 (dwa krótsze cytaty: nr 65, s. 406; dłuższy: nr 67, s. 411). 
już walory „foksalu”, nowinki, która nad Newę także zawędrowała z Zachodu. Foksal z warszawskiego Nowego Światu był, podobnie jak ten w Jekaterinhofie, także częścią naszej kultury przedkolejowej.

Osobliwością foksalu pawłowskiego było jego ulokowanie w bezpośrednim sąsiedztwie stacji kolejowej, gdzie kończył się szlak Kolei Carskosielskiej. Ale od samego początku istniały w parku dwa różnie nazywane obiekty: skromna stacja (gdzie przyjmowano i odprawiano gości z Sankt Petersburga) i wykwintny foksal (który tych gości do Pawłowska przyciągał). Dziewiętnastowieczne przewodniki Baedekera nie pozostawiają w tej kwestii żadnych wątpliwości. Czytamy w nich o tym, że tuż przy stacji położona jest „restauracja, zwana foksalem [...], gdzie codziennie latem dobra orkiestra daje wieczorami cieszące się dużą frekwencją koncerty"18. Dołączona do przewodników szczegółowa mapa unaocznia bliskość, a zarazem odrębność stacji i foksalu ${ }^{19}$. Krótko po uruchomieniu Kolei Carskosielskiej i udostępnieniu przyjezdnym pawłowskiego foksalu został zbudowany pierwszy odcinek Drogi Żelaznej Warszawsko-Wiedeńskiej. Odcinek do Grodziska przyniósł powtórzenie założeń zrealizowanych w Pawłowsku: kolej miała ściągać pasażerów, którzy byli spragnieni zabawy i miłych spacerów w podwarszawskich parkach w Pruszkowie i w Grodzisku (później tę listę uzupełniły jeszcze Skierniewice i Łowicz). W jednej z najwcześniejszych relacji z podróży pociągiem czytamy:

Lotem ptaka spadliśmy na Pruszków, gdzie zgrabny foksal według planu p[ana] Löwe ma być wkrótce ukończony, a jak słychać, zimą mają tam być bale i baliki. Cieszcie się warszawianie! Nie mogliśmy obejrzeć Sali, bo rozdąsana lokomotywa syczy, gwiżdże; więc dalej na miejsca, i zaledwie można było przekonać się, że jedziemy, aż tu przed nami stoi Grodzisk, a przy nim znowu piękny foksal z wieżą podług projektu p[ana] Schillera.

18 K. Baedeker Russland. Handbuch für Reisende, mit 14 karten, 18 plänen und 4 grundrissen, vierte auflage, Leipzig 1897, s. 188; tegoż La Russie. Manuel du voyageur, avec 14 cartes et 22 plans, deuxième edition, Leipzig 1897, s. 180; tegoż Russia with Teheran, Port Arthur, and Peking. Handbook for travelers, with 40 maps and 78 plans, Leipzig 1914, s. 189.

Dziewiętnastowieczna mapa pokazuje przestrzeń, która dziś bardzo się zmieniła. Budynek foksalu został zniszczony w 1917 roku. Nie ma także stacji kolejowej, która niegdyś znajdowała się tuż obok: dzisiejsza stacja zlokalizowana jest w innym miejscu (jakieś 2 km na zachód od poprzedniej) i ma charakter stacji przelotowej (oryginalna Kolej Carskosielska kończyła się w Pawłowsku). Jedynym śladem po wspaniałej przeszłości foksalu w Pawłowsku jest tablica pamiątkowa, wskazująca miejsce, gdzie w czerwcu 1838 roku został otwarty "Павловский музыкалный ВОКЗАЛ". Zdarza się i to, niestety, często, że współczesną stację w Pawłowsku pokazuje się jako miejsce zdarzeń z foksalu z powieści Dostojewskiego. 
I w nim będzie duża sala, gładka posadzka, gdzie niejedna Polka prześliźnie się przy odgłosie muzyki. ${ }^{20}$

Nie zachowały się żadne ślady po foksalu pruszkowskim, nie wiemy, jak mogła wyglądać budowla, do której dojeżdżało się z Warszawy „pociaggiem spacerowym"21. Więcej szczęścia miał foksal w Grodzisku. Stoi dumnie do dzisiaj, a zobaczyć go można chwilę przed tym, nim pociąg z Warszawy osiągnie perony grodziskiej stacji. „Foksal” w XIX-wiecznej polszczyźnie długo jeszcze miał sens zarejestrowany przez Энциклопедический лексиконъ i odnosił się do restauracji, z salami przeznaczonymi do organizowania zabaw (bez względu na lokalizację, jaką miała). Dokumentuje to m.in. okazały obiekt z parku w Druskiennikach, wzniesiony w czasach, gdy to popularne uzdrowisko nie miało jeszcze połączenia kolejowego. W charakterystyce miasta, przygotowanej przez inicjatora budowy foksalu, czytamy:

Foksal, a w nim wielka sala balowa i koncertowa, z galeriami dla przechadzki w czasie niepogody. Przy foksalu biblioteka, składająca się ze znacznego wyboru książek rosyjskich, polskich, francuskich, niemieckich i angielskich, oraz wielkiej ilości w rozmaitych językach pism periodycznych i gazet. W tymże foksalu sale: bilardowa, na pomieszczenie fortepianów, restauracja, table d'hôtes, skład win Elisiejewa z Petersburga. ${ }^{22}$

Mniej więcej w tym samym czasie, tj. w połowie XIX wieku, w języku rosyjskim zaczyna się dokonywać przesunięcie semantyczne. Słowo „воксал” zaczyna być rozciągane także na stację kolejową, która - jak w przypadku

20 "Kurier Warszawski” 1845 nr 267, s. 1286; piszę o tym więcej w szkicu Inni romantycy, inny romantyzm, otwierającym tom: Inna droga. Romantycy a kolej, Wydawnictwo IBL PAN, Warszawa 2012, s. $29-38$.

21 Ospacerowym" charakterze wczesnych podróży do Grodziska (a z czasem - także do Skierniewic i Łowicza) świadczą nie tylko wczesne relacje (prasowe i literackie). Cechę tę ujawniają też charakterystyczne praktyki związane z rozkładem jazdy. Rozkład ten latem 1845 roku był podawany w "Kurierze Warszawskim” w rubryce poświęconej informacjom o repertuarze teatrów. Zmianę tego rozkładu narzuciły przedsiębiorstwu krótsze jesienne dni („Z powodu krótszych obecnie dni pociągi popołudniowe drogi żelaznej w dnie powszednie dotąd o godz. 4 z Warszawy wyruszające, poczynając od jutra odchodzić będą z Warszawy o godz. 3 po południu“; „Gazeta Codzienna" 1845 nr 258).

22 J. Pilecki Druskienniki w roku 1873, "Gazeta Lekarska” 1874, t. 17, nr 1, s. 2. Wcześniej czytamy, że uzdrowisko leży „o 17 wiorst od stacji Petersbursko-Warszawskiej Drogi Żelaznej, Porzecze” (s. 1). 
Pawłowska - często stanowiła tylko skromny dodatek dla okazałej „restauracji”. W Idiocie Dostojewskiego ten proces semantyczny zaznacza się dwojako: tym, że wszystkie dworce Sankt Petersburga (Warszawski, Mikołajewski i Carskosielski) wskazywane są słowem „воксал”23 i tym, że dla foksalu w Pawłowsku i położonej obok niego stacji ma jeszcze pisarz dwa osobne słowa. W Idiocie prawie wszystkie sceny z Pawłowska rozgrywają się na tamtejszym foksalu. I wszędzie tam, gdzie w odniesieniu do Pawłowska pada „воксал”, polskim ekwiwalentem winien stać się „foksal” (objaśniony jako rodzaj dużej restauracji). W jednej tylko scenie Dostojewski przenosi nas na stację. Czytamy wtedy: „ - На железную дорогу [...]!” і „доскакали до станции вовремя" (D 616). U Jędrzejewicza mamy: „ - Na dworzec [...]!” i „dojechali do stacji” (J 624), u Gładyś: „- Na stację kolejową [...]!” i „dognali na czas do stacji" (G 679). Wystarczy podstawić w scenie z Jekaterinhofu „foksal" (w znaczeniu wykwintnej restauracji, nie zaś - ogrodu botanicznego), a dostaniemy przystawalność miejsca i zachowań Nastazji Filipownej. Tę samą przystawalność osiągniemy, gdy „dworzec” z przekładu Jędrzejewicza zamienimy na „foksal” (wciąz, rzecz jasna, w znaczeniu: restauracja), przestanie nas bowiem razić muzyka, której się w tym miejscu u Dostojewskiego słucha. Po tych dwóch zabiegach Rosja znormalnieje, uświadamiając, że relacje nasze - obce rysowały się tam w XIX wieku podobnie jak tu w Polsce, że - wyraziwszy się dobitniej - akcja Idioty toczy się świecie, który kiedyś (w XIX wieku) miał nad Newą i nad Wisłą kształty bardzo podobne i oferował te same atrakcje.

Dziewiętnastowieczna kultura foksali to zjawisko słabo rozpoznane. A stanowiło ono część szerszego procesu, który można nazwać technologizowaniem rozrywki. Powołał on do życia rozwiązania, w których praktyka kulturowa silnie splatała się z nowoczesną techniką. Wymienię najważniejsze: panorama, diorama, fotoplastykon, kinematograf, park zabawowy (z kolejkami górskimi, kołami-gigantami i aranżacjami katastrof naturalnych). W XVIII-wiecznych foksalach-ogrodach zastosowań techniki było jeszcze niewiele. Bywalcy warszawskiego foksalu, prócz słuchania muzyki, mogli wszakże oglądać efektowne loty balonów na ogrzane powietrze lub zachwycać się pokazami sztucznych ogni (fajerwerków) ${ }^{\mathbf{2 4}}$. Foksale z epoki

23 Raz Dostojewski sięga po kalkę z języka francuskiego i pisze: „На дебаркадере Царскосельской железой дороги" (D 525).

24 Kunszt przygotowania fajerwerków z warszawskiego ogrodu-foksalu objawiał się tym, że były one - przypomnę - "bez żadnego odoru". 
kolejowej charakteryzują się znacznie wyższym nasyceniem nowoczesnymi technologiami. Na wyposażenie wznoszonego foksalu w Pawłowsku Franz Gerstner zamówił nie tylko „dwa aparaty do miejsca potrzeby (water-closets)”, ale też - powtórzę - „sześć mechanicznych krzeseł tak urządzonych, iż siedzący oparciem o poręcze [...] mógł dowolnie zmieniać kształt fontanny"25. W naszych rodzimych doniesieniach o atrakcjach, jakie oferowała Droga Żelazna Warszawsko-Wiedeńska, przyjął się schemat lokalizacyjny „foksal przy stacji”, można było wszakże powiedzieć „foksal na stacji”, podkreślając, że chodzi o dwa obiekty funkcjonalnie ze sobą spojone. W Pruszkowie, Grodzisku, Skierniewicach i Łowiczu stacja kolejowa i sama kolej stanowiły technologiczną przystawkę do serwowanej wszędzie głównej potrawy, to jest wybornej restauracji, z muzyką i salą do tańców. Połączenie obu funkcji (użytkowej i rozrywkowej) w jednym budynku doprowadziło do przesunięcia semantycznego, podobnego do tego, które dokonało się w języku rosyjskim. Tam „воксал” (z pisownią „вокзал”) stał się od końca XIX wieku podstawowym apelatywem identyfikującym stację kolejową (zwłaszcza dużą, wyposażoną w dodatkowe wygody). W języku polskim tylko przez jakiś czas pożyczony „foksal” mógł konkurować z rodzimym „dworcem"26. Oba przesunięcia semantyczne, rosyjskie (zakończone definitywnym utożsamieniem restauracji i stacji kolejowej) i polskie (gdzie „foksal” tylko przez jakiś czas mógł zastępować „dworzec”) są pochodną wspomnianego procesu technologizowania rozrywki.

W obu analizowanych polskich przekładach Idioty dochodzi do tego, co (niektórzy przynajmniej) kulturoznawcy nazywają „przemapowaniem”27. Polska czasów, w których Dostojewski pisał swą powieść, była częścią Rosji i ciążyła wyraźnie ku kulturze Wschodu. Wschodni był m.in. sposób absorbowania najnowocześniejszej technologii, ponieważ - jak pokazuje przykład pierwszego odcinka Drogi Żelaznej Warszawsko-Wiedeńskiej - technika kolejowa trafiała nad Wisłę za pośrednictwem sfery rozrywki. Symbolem tego etapu kulturowego rozwoju jest zarówno foksal (pruszkowski, grodziski, skierniewicki czy łowicki), jak i obsługujący go „pociąg spacerowy”. Wspomniane „przemapowanie" polega na tym, że w obu współczesnych tłumaczeniach Idioty na Rosję patrzymy ze zdziwieniem i zażenowaniem. Widzimy

25 Pierwsza żelazna droga w Rosji, "Tygodnik Petersburski” 1836 nr 65, s. 406.

26 Zob. J. Karłowicz, A.A. Kryński, W. Niedźwiedzki Słownik języka polskiego, t. 1, Warszawa 1900, s. 757.

27 Zob. D. Bachmann-Mendick Nowe kierunki w nauce o kulturze, s. 337. 
wszakże kraj, który chcemy zobaczyć. Przekłady produkują Inność, z którą dobrze się czujemy. Tu jest Polska, tam Rosja - pijana i nieprzewidywalna. Bo przecież Rosji nie lubiliśmy i wciąż nie lubimy ${ }^{28}$.

\section{Abstract}

\section{Wojciech Tomasik}

KAZIMIERZ WIELKI UNIVERSITY (BYDGOSZCZ)

An Orgy at Yekaterinhof Station: On the Creation of Otherness in Translations os Dostoevsky's The Idiot

This article explores how Otherness is created in two Polish translations of Dostoevsky's The Idiot. The analysis focuses on scenes whose localisation the Russian original describes as воксал (read: vauxhall, meaning'railway station'). This word first appears in the characterization of Anastassya Filippovna (in a sentence about her participation in the orgy at Yekaterinhof); later it is used consistently to describe the events set in Pavlovsk. The translations mention an orgy 'at the station' [na 'dworcu'] in Yekaterinhof as well as concerts that drew the characters staying in Pavlovsk to the botanical gardens. This corresponds to the popular image of Russia as a land of the unforeseeable and of radical cultural difference. In the translations of The Idiot Russia is subject to're-mapping' (pushing away from us).

\section{Keywords}

translation, train station (vauxhall, воксал), re-mapping

28 W zaprezentowanej analizie nie biorę pod uwagę przedwojennego przekładu Heleny Grotowskiej. Scena jekaterinhofska nie ma tu żadnej lokalizacji i wygląda tak: „w tydzień mniej więcej po strasznej orgii w Jekaterynhofie, w której wzięła udział i Nastazja Filipowna" (T.M. Dostojewski Idiota, Część I, przełożyła z oryginału H. Grotowska, Towarzystwo Wydawnicze "Rój”, Warszawa 1928, s. 203). W partiach, które dzieją się w foksalu w Pawłowsku, tłumaczka korzysta z "dworca", co w jednym miejscu istotnie zmienia obraz. Oto bowiem czytamy: „Wypadek na dworcu napełnił matkę i córki przerażeniem" (tamże, Część druga, s. 37). U Jedrzejewicza jest: „Wydarzenie przy dworcu napełniło matkę i córki przerażeniem" (J 372), u Gładyś zaś: „Zarówno na mamę jak i córki wydarzenie na foksalu podziałało niemal paraliżująco" (G 405), a u Dostojewskiego: „Происшествие в воксале поразило и мамашу и дочек почти ужасом" (D 368). „Wypadek na dworcu" może nasuwać skojarzenia z nieszczęściem Anny Kareniny... 